\title{
A new species of the genus Periclimenes (Decapoda: Caridea: Palaemonidae) collected from hydrothermal vent fields in Kagoshima Bay, Japan
}

\section{Ken-Ichi Hayashi and Jun Ohtomi}

\begin{abstract}
Based on material collected from shallow hydrothermal vent fields in Kagoshima Bay, southern Japan, a new species of the subfamily Pontoniinae, Periclimenes thermohydrophilus, is described and illustrated. A combination of several characters distinguishes the present new species from all other members of this genus. A short and narrow rostrum without basal crest, an isolated epigastric spine, a submarginal antennal spine and a long carpus of the second pereopod are characteristics of the new species. The relationship between this shrimp and host tube worms is briefly discussed.
\end{abstract}

\section{Introduction}

Recently shallow hydrothermal vent fields were explored in the eastern end of Kagoshima Bay and an interesting associated fauna was discovered (Hashimoto et al., 1993; Miura et al., 1997). The junior author and his colleagues carried out many cruises while researching the decapod fauna of Kagoshima Bay including these vent fields. Considerable numbers of unusual shrimps were found in the tube worm colonies at depths of about 100 $\mathrm{m}$. They constitute a single species of the genus Periclimenes Costa, 1844. This is the first species of the family Palaemonidae collected from the hydrothermal vent fields. Species of the families Alvinocarididae Christoffersen, 1986 and
Mirocarididae Vereshchaka, 1997 are the typical vent carideans (Gebruk et al., 1997). No species of the family Palaemonidae has been known from these environments so far, while a few species of Hippolytidae, Crangonidae and Oplophoridae have been reported (Desbruyéres \& Segonzac, 1997; Tunnicliffe et al, 1998).

Periclimenes is a large genus containing more than 170 species and most species are commensal with scleractinean corals or their associated invertebrates in tropical and subtropical waters (Chace \& Bruce, 1993; Bruce, 1994). Recently several species of this genus have been described from deep waters, more than 100 $\mathrm{m}$ deep (Bruce, 1990, 1991b, 1996). Although collected from a curious and comparatively deep habitat, the present species has the general form of the genus. Careful comparison with the related deep-water congeners, however, reveals that the present species is distinguished from them in having a short and narrow rostrum, an isolated epigastric spine, a submarginal antennal spine, and unarmed long carpus of the second pereopods.

All specimens examined are deposited in the collection of the National Fisheries University (NFU). The carapace length (CL) represents the specimen size, measuring from the posterior margin of the orbit to the posterior margin of the carapace. 
Systematic account

\section{Periclimenes thermohydrophilus new species}

Figs. 1-4

Material examined.-Holotype, ovig. i (NFU 530-2-2367, 6.1 mm CL), Kagoshima Bay, "Shinkai 2000," dive 980, depth 90-100 m, associated with Lamellibrachia satsuma, 30 September 1997, coll. T. Miura.

Paratypes: 2 ovig. + (NFU 530-2-2369, CL 6.0, $7.0 \mathrm{~mm}$ ), Kagoshima Bay, "Dolphin $3 K$," dive $340,31^{\circ} 39.5^{\prime} \mathrm{N}, 130^{\circ} 48.2^{\prime} \mathrm{E}$, depth $97 \mathrm{~m}$, associated with Lamellibrachia satsuma, 1 September 1997, coll. T. Miura; - 11 ovig. \& (NFU 530-2-2368, CL 4.4-6.6 mm), 1 9 (CL 5.3 $\mathrm{mm})$, collected together with holotype; 4 ơ (NFU 530-2-2370, CL 3.4-4.4 mm), 1 of (CL $6.8 \mathrm{~mm})$, northern part of Kagoshima Bay, depth 105 m, hydrothermal vent field, 20 April, 2001, coll. J. Ohtomi.

Description of holotype.-Moderate sized species (Fig. 1). Rostrum compressed, slender and gradually tapered; directed straight forward, not reaching distal end of antennular peduncle (Fig. 3A). Lateral carina not developed, dorsal margin with 8 teeth, posterior 4 teeth closely set, of which posterior 2 on carapace, third tooth just above orbital margin; 3 equidistant teeth on distal half of ventral margin; distal tooth small (Fig. 3A). Carapace glabrous, smooth, with shallow hepatic depression below hepatic spine posterior to anterior half of carapace. Epigastric spine situated at anterior third of carapace, considerably separated from last tooth of rostral series (Fig. 3A, B); dorsal margin between epigastric spine and last rostral tooth convex in lateral view; indistinct tubercle present just posterior to epigastric spine (Fig. 3A). Middorsal carina vanishing behind tubercle. Antennal spine slender, submar- ginal, situated just inside anterior margin of carapace, apex reaching rounded suborbital angle (Fig. 3D). Anterolateral margin from suborbital angle to pterygostomial angle gently convex. Pterygostomial angle largely rounded.

Abdominal somites smooth, glabrous. Few simple setae on terga of fifth and sixth somites only. Third somite not produced posteriorly. Pleura of first three somites broadly rounded; those of fourth and fifth somites produced posteriorly, not sharply pointed, fifth more pointed than fourth (Fig. 3E). Sixth somite 1.8 times as long as fifth somite and 1.4 times as long as deep, posterolateral and posteroventral angles both acute (Fig. $3 \mathrm{E})$. Telson 1.4 times as long as sixth somite, moderately slender, lateral margin nearly straight. Dorsolateral spines in 2 pairs, but small additional spine distal to distal pair on left side, proximal pair at midlength of telson, distal pair at midlength between proximal pair and distal margin. Distal margin with 1 central spine and 3 pairs of unequal spines (Fig. $3 \mathrm{~F})$.

Eyes moderate, with well-pigmented cornea, with small ocellus, eyestalk slightly longer than cornea, swollen mesially (Fig. 3G). Antennular peduncle moderate, reaching distal margin of antennal scale (Fig. 3B). First segment of peduncle twice as long as wide, with mesial margin straight, entirely setose, with small ventral spine; lateral margin slightly convex mesially ending in acute spine reaching nearly midlength of second segment; distolateral lobe developed (Fig. 3B, H). Stylocerite acute, slender, overreaching midlength of first antennular segment. Second and third antennular segments cylindrical, equal in length, much slenderer than first segment; lateral and mesial margins of second segment setose. Upper antennular flagellum biramous, with 7 or 8 proximal segments fused and unarmed. Shorter free ramus 


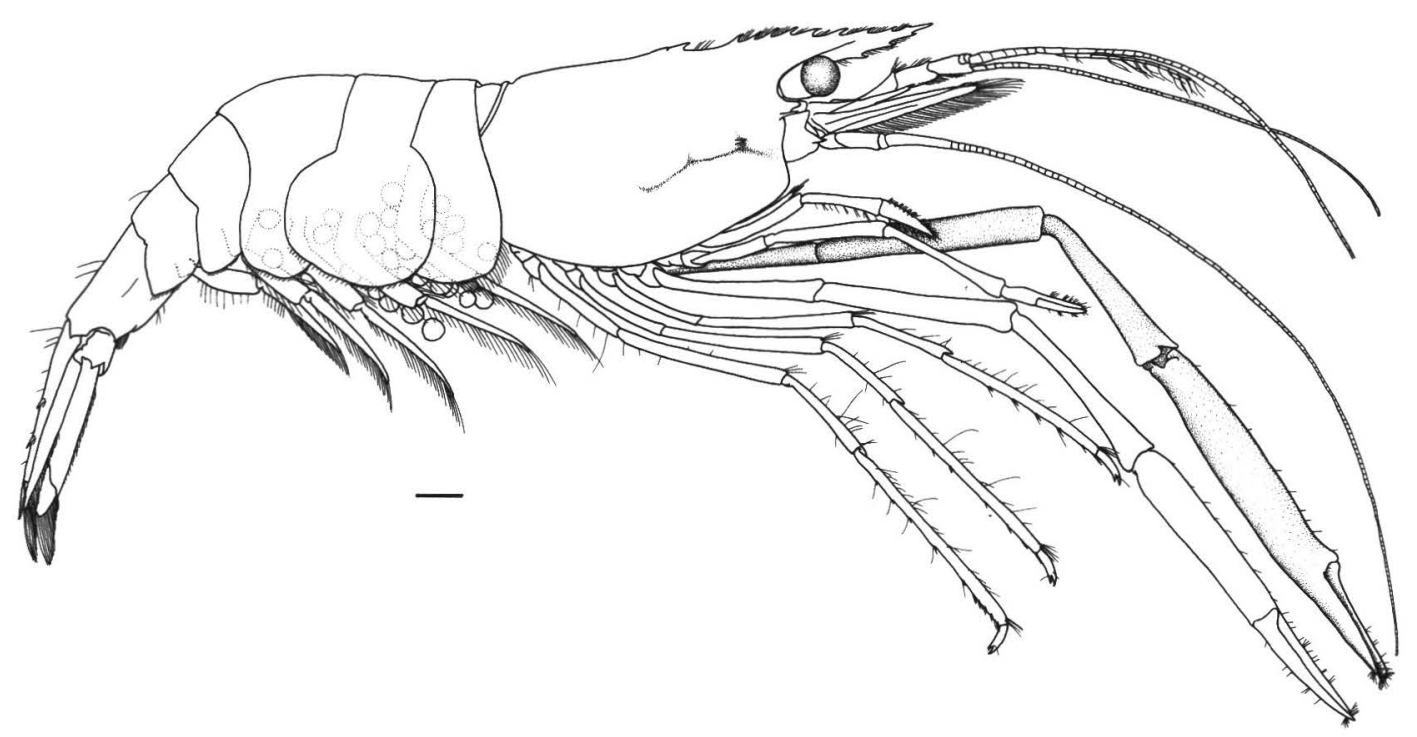

Fig. 1. Periclimenes thermohydrophilus new species. Holotype, ovigerous female, CL $6.1 \mathrm{~mm}$ (NFU 530-2-2367) from Kagoshima Bay. Scale $=1.0 \mathrm{~mm}$.

with about 10 segments, as long as fused portion, each segment with few aesthetascs; longer ramus not complete, more than twice as long as shorter ramus. Lower flagellum slender, filiform, not complete, as long as upper flagellum. Antenna with basicerite bearing small distolateral tooth; dorsodistal corner produced, but blunt. Carpocerite cylindrical, reaching proximal third of scaphocerite. Scaphocerite broad, 0.6 times as long as carapace, 2.4 times as long as wide; lateral margin nearly straight; distolateral tooth stout, slightly falling short of distal margin of rounded blade. Flagella not complete, extending forward to distal end of second chela.

Mouthparts (Fig. 4A-F) not different from typical form of genus. Mandible without palp; incisor process well developed, with 4 acute teeth, molar process stout, with several blunt teeth (Fig. 4A). First maxilla with bilobed palp, upper and lower laciniae densely setose distally (Fig. 4B). Second maxilla with simple naked palp; basal endite deeply bilobed, upper lobe slightly larger than lower lobe, both setose distally; coxal endite obsolete; scaphognathite well developed (Fig. 4C). First maxilliped with slender tapering palp, reaching distal margin of basal endite, with subterminal seta; basal endite large, broadly rounded distally, densely setose; coxal endite small, thickened, sparsely setose; exopod with flagellum well developed, broad, with several long plumose setae, caridean lobe large, epipod large, weakly bilobed (Fig. 4D). Second maxilliped with normal endopod with distal segment short and wide setose distally; exopod long, with several long setae distally and short setae on mesial margin; epipod large, rectangular (Fig. $4 \mathrm{E})$. Third maxilliped normal, moderately elongate and slender, reaching rostral apex (Fig. 4F). Distal segment little shorter than half of third segment, tapering distally, mesial margin with several groups of strong setae; second segment 1.2 times longer than distal segment, mesial margin sparsely setose; third segment faintly articulated with basis, mesial margin with sparse long setae, distolateral part with 2 (right) or 4 (left) 


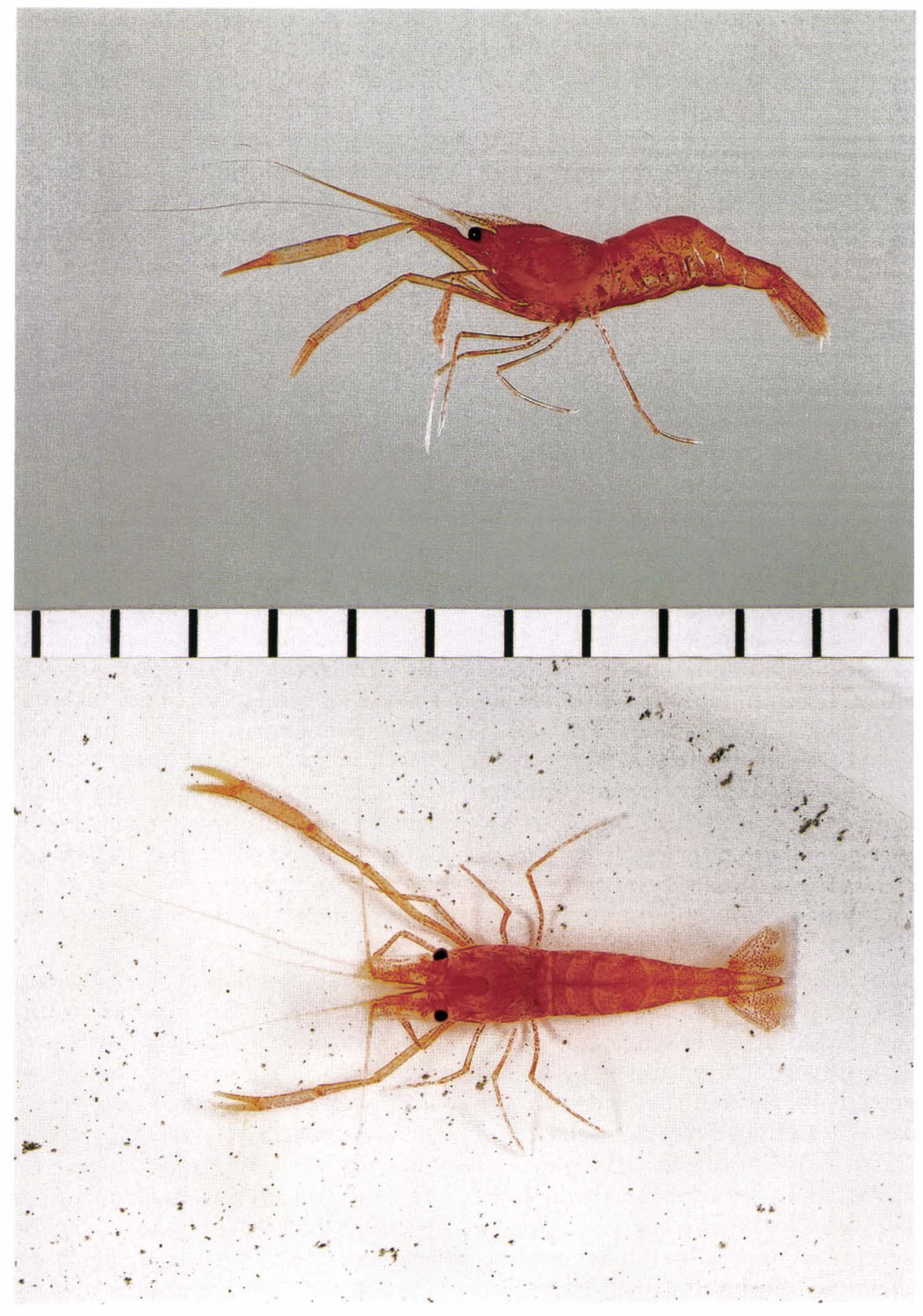

Fig. 2. Periclimenes thermohydrophilus new species. Paratype, female, CL 6.8 mm (NFU 530-22370) from Kagoshima Bay. Lateral (upper) and dorsal (lower). Scale $=0.5 \mathrm{~mm}$. 
spinules; basis sparsely setose; exopod long, with distal setae only; coxa feebly produced mesially, sparsely setose, with small oval plate laterally, without arthrobranch.

Epistome with pair of low rounded processes. Fourth thoracic sternite without median process but with posterior plate as on fifth sternite; these posterior plates with median deep incision.

First pereopod slender, exceeding distal end of antennular peduncle by chela (Figs. 1, 4G); palm of chela cylindrical, with 5 rows of short setae on ventral surface near carpal articulation; fingers 1.8 times as long as palm, bearing some groups of setae, cutting edge smooth (Fig. $4 \mathrm{H})$. Carpus 1.6 times as long as chela, cylindrical, slightly tapered proximally, with tuft of long setae distoventrally. Merus 0.8 times as long as carpus and 1.4 times as long as chela, slightly swollen centrally. Ischium as long as chela, obliquely articulated with basis (Fig. 4G)

Second pereopods similar in shape and very slightly unequal in length; both legs exceeding distal end of antennular peduncle by carpus and chela (Fig. 1); fingers, carpus and merus 1.1 times and palm 1.3 times longer in left than in right; chela smooth, glabrous, cylindrical, 1.3 (right) or 1.5 (left) times longer than carapace. Fingers 0.7 (right) or 0.6 (left) times as long as palm, with strongly hooked tips, sparsely setose; cutting edges sharp, entire on distal three-fifths, and with several small teeth on remaining proximal part (Fig. 4J). Carpus 0.9 (right) or 0.8 (left) times as long as palm, unarmed, expanded distally. Merus 1.0 (right) or 0.9 (left) times as long as palm, cylindrical, unarmed; ischium slightly shorter than merus, cylindrical, unarmed (Fig. 4I).

Ambulatory pereopods slender, similar in shape and size, all overreaching tip of first pereopod by dactylus (Fig. $4 \mathrm{~K}, \mathrm{M}$, N). Dactylus of third pereopod gently curved, simply biunguiculate, lower ac- cessory tooth overreaching midpoint of unguis (Fig. 4L). Propodus 4.8 times as long as dactylus; ventral margin with 2 rather long distoventral spines, preceded by 5 separate spines, all spines with few setae; dorsal margin sparsely setose (Fig. 4L). Carpus about half as long as propodus, unarmed; merus about 0.9 times as long as propodus, unarmed; ischium about 0.6 times as long as merus, unarmed (Fig. 4K). Fourth and fifth pereopods similar in shape and proportion (Fig. 4M, N); propodus of fifth pereopod with row of 4 or 5 separate spines on ventral margin, and one pair of spines on distal end, all obscured by 5 rows of setae (Fig. 4P).

First pleopods (female) unequally biramous. Endopod short, about one-fourth length of exopod, both densely setose. Second to fifth pleopods biramous in nearly equal length, densely setose, endopod with long slender appendix interna. Uropods longer than telson, protopod with acute posterolateral process; endopod slightly shorter than exopod, about 4 times as long as broad; exopod ending in small spine on outer distal end, accompanying with longer movable spine just inside; diaeresis well marked, smooth (Fig. $3 \mathrm{~F})$.

Variation of paratypes.-Rostrum not extending beyond distal end of antennular peduncle. Of 19 paratypes 18 with intact rostrum, comparative length varying from 0.50 to 0.68 times as long as carapace. Armature also variable, upper margin with 7 teeth in 2 specimens, 8 teeth in 9 specimens, 9 teeth in 5 specimens, and 10 teeth in 2 specimens, 2 (in 5 specimens) or 3 teeth (in 13 specimens) of these on carapace. Lower margin with 1 tooth in 3 specimens, 2 teeth in 13 specimens, and 3 teeth in 2 specimens. One male $(3.4 \mathrm{~mm}$ CL) entirely lacking epigastric spine or small tubercle; large specimens usually with both but remaining males with epigastric spine only. 


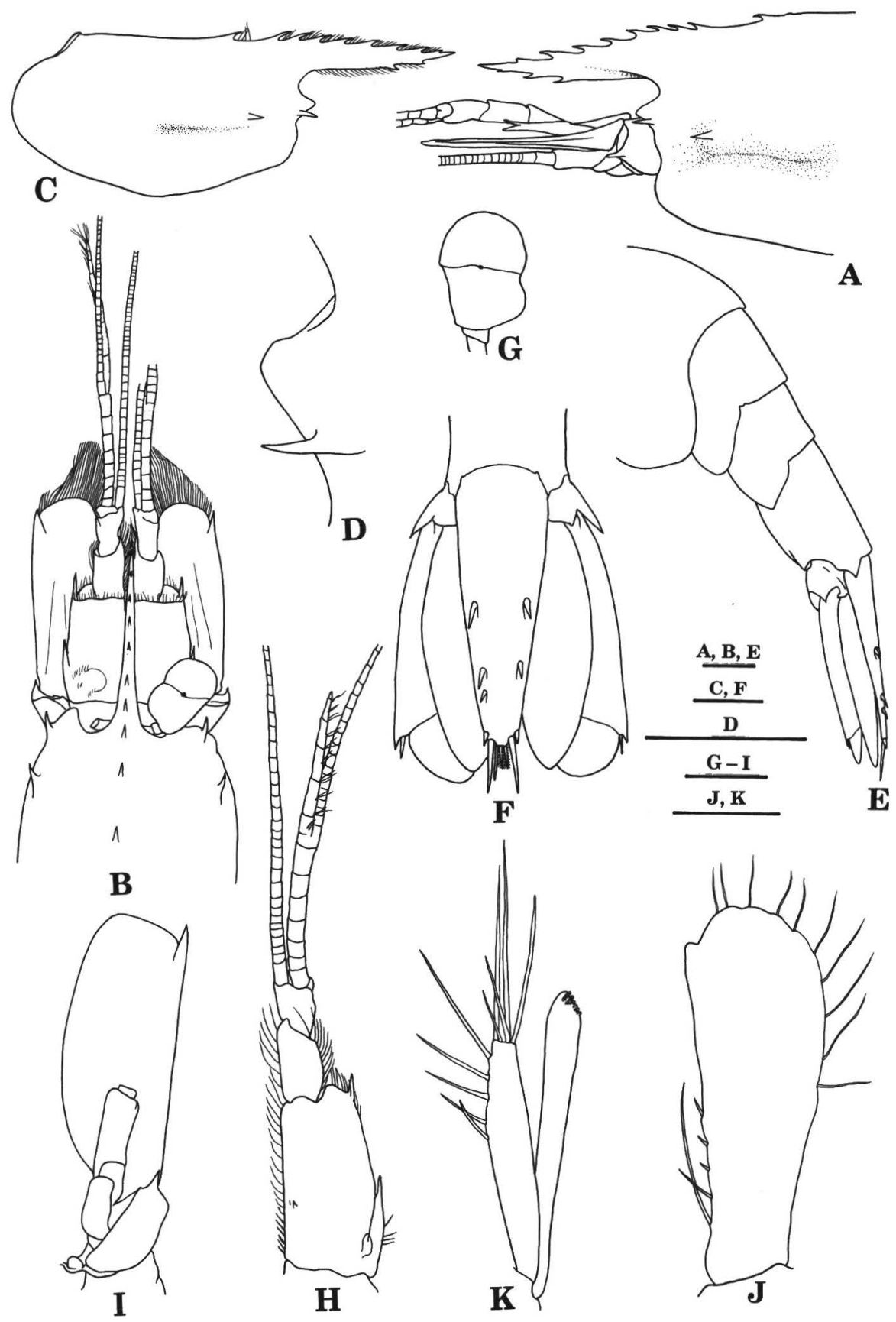

Fig. 3. Periclimenes thermohydrophilus new species. A, B, D-F, holotype, ovigerous female, CL $6.1 \mathrm{~mm}$ (NFU 530-2-2367); C, J-K, paratype, male, CL $4.4 \mathrm{~mm}$ (NFU 530-2-2370); G-I, paratype ovigerous female, CL $6.8 \mathrm{~mm}$ (NFU 530-2-2368); all from Kagoshima Bay: A, anterior part of carapace, with cephalic appendages, lateral; B, same, dorsal; C, carapace, lateral; D, anterior margin of carapace, lateral; E, posterior part of abdomen, lateral; F, tail fan, dorsal; G, eye, dorsal; H, first antenna, ventral; I, second antenna, ventral; J, endopod of left first pleopod; K, appendix interna and appendix masculina of left second pleopod. Scales for A-I $=1.0 \mathrm{~mm}$; scale for $\mathrm{J}, \mathrm{K}=0.2 \mathrm{~mm}$. 


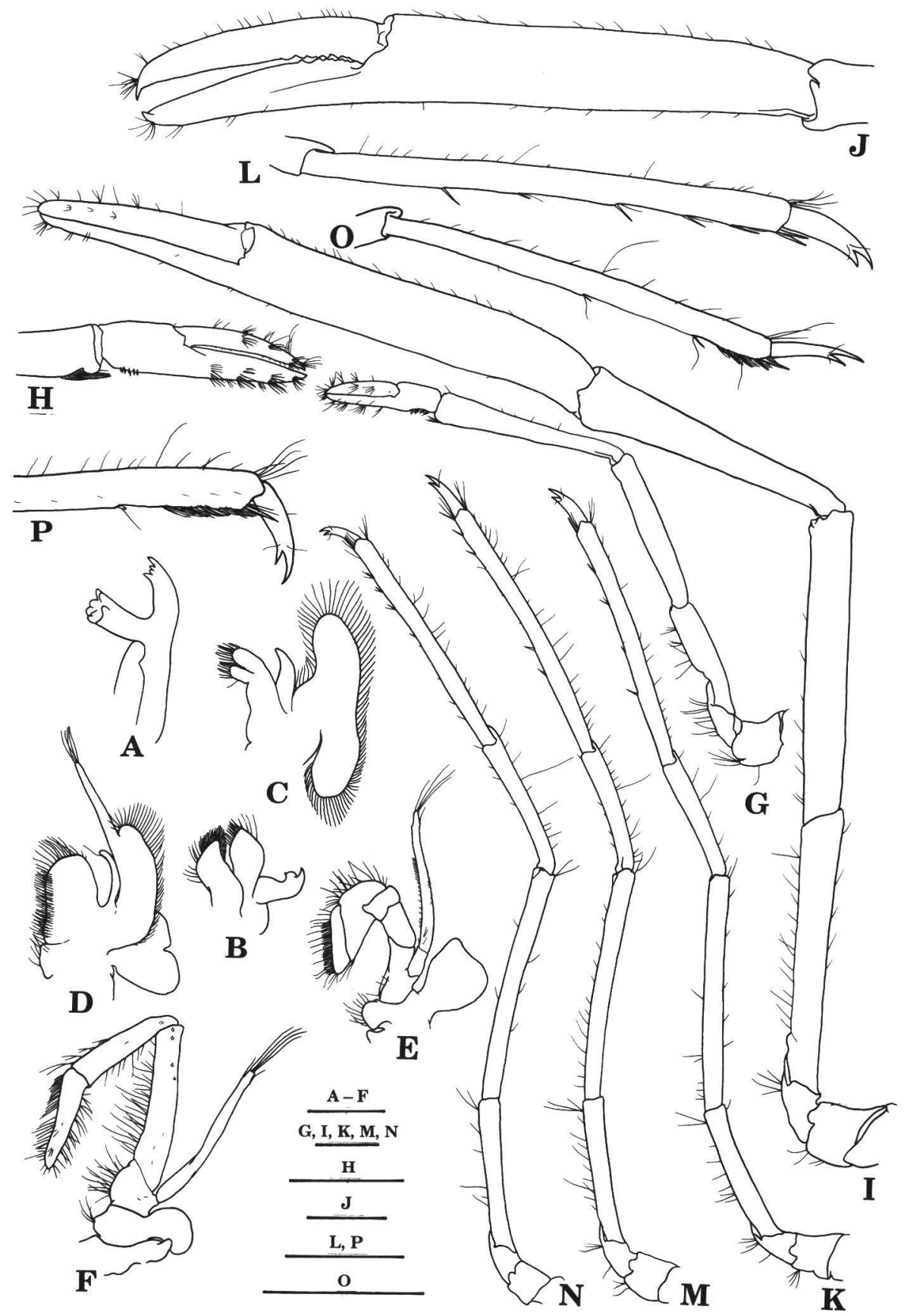

Fig. 4. Periclimenes thermohydrophilus new species. A-F, paratype, ovigerous female, CL 6.8 mm (NFU 530-2-2368); G-N, P, holotype, ovigerous female, CL $6.1 \mathrm{~mm}$ (NFU 530-2-2367); O, paratype, male, CL 4.4 mm (NFU 530-2-2370); all from Kagoshima Bay; A- N, left side; O, P, right side: $A$, mandible; $B$, first maxilla; $C$, second maxilla; $D$, first maxilliped; $E$, second maxilliped; F, third maxilliped; G, first pereopod, lateral; H, same, chela, mesial; I, second pereopod, lateral; J, same, chela, lateral; K, third pereopod, lateral; L, same, distal two segments, mesial; $M$, fourth pereopod, lateral; $N$, fifth pereopod, lateral; $O$, same, distal two segments, lateral; $P$, same, dactylus and distal part of propodus, lateral. Scales $=1.0 \mathrm{~mm}$. 
Sixth abdominal somite 1.7-2.1 times as long as fifth somite and 1.4-1.8 times as long as deep. Telson 1.3-1.6 times as long as sixth somite. Dorsolateral spines usually in 2 pairs, one specimen with only 1 pair, two specimens with unequally 1 spine or 3 spines on either side. Upper antennular flagellum with 5-7 basal joints and biramous distal part; shorter ramus composed of 10-14 free joints, as long as or slightly longer than carapace. Longer ramus of upper flagellum and lower flagellum, distal part missing, more than 3.5 times as long as carapace. Scaphocerite 1.9-2.7 times as long as wide; outer distal spine shorter or longer than distal margin of lamella. Distal part of antennal flagellum usually missing, but more than 5 times as long as carapace length.

Two or more spinules on third segment of third maxilliped present; of 18 paratypes with third maxillipeds on both sides, 8 specimens with 3 spinules, and 2 specimens with 2 or 4 spinules on both sides, 3 specimens unequally with 2 and 3 spinules, one specimen with 3 and 4 spinules and 2 specimens with unequally 5 and 6 spinules on one side; number of spinules related neither to sex nor specimen size; these spinules usually situated at distal third of lateral surface in case of less than 3 spinules, but posterior 1 or 2 spinules at midlength of segment in case of 4 or more spinules.

Seven specimens bearing pair of second pereopods, 4 specimens with second pereopod on only one side and 8 specimens lacking those from both sides. One male (4.4 mm CL) with nearly equal pair, but other females with slightly unequal chelipeds, all reaching beyond scaphocerite by carpus and chela or chela only. Major chela 1.05-1.60 times as long as minor chela; each segment of major and minor chelipeds with nearly same proportion as chela. Carpus 0.8-1.0 times as long as palm; merus as long as or slightly longer than carpus.
Males smaller and more slender than females, especially shorter and slenderer in pereopods but not clearly different from females (Figs. 3C, 4O). Endopod of male first pleopod leaf-shaped, broadened distally, outer distal margin convex, with 10 plumose setae; inner margin slightly concave, with a rather long plumose seta near proximal end and 4 short simple setae on proximal half (Fig. 3J). Male second pleopod equally biramous. Endopod with appendix interna and appendix masculina, appendix interna longer than corpus of appendix masculina, with 5 simple setae on distal half of mesial margin and 5 unequal apical setae (Fig. 3K).

Size.-The holotype is an ovigerous female, $6.1 \mathrm{~mm}$ CL and about $22.5 \mathrm{~mm}$ in total length. The paratypes are 4.6-7.0 $\mathrm{mm} \mathrm{CL}$ in ovigerous females and 3.4-4.4 $\mathrm{mm}$ CL in males. Eggs small, $0.43-0.45 \mathrm{x}$ $0.46-0.50 \mathrm{~mm}$ in uneyed eggs and 0.50 $0.53 \times 0.63-0.66 \mathrm{~mm}$ in eyed eggs. The holotype carries 260 uneyed eggs, the smallest ovigerous female, $4.4 \mathrm{~mm} \mathrm{CL}$, has 140 eyed eggs and the largest one, 7.0 $\mathrm{mm}$ CL, has 510 uneyed eggs.

Color.-Body entirely crimson red (Fig. 2). Rostrum and uropod semitransparent, with many red chromatophores. Cornea black, eyestalk and antennular peduncle crimson red. Antennular flagella, antennal flagellum and thoracic appendages including second pereopod reddish orange.

Etymology.-The species name, thermohydrophilus, is the combination of the Greek, "thermos" (= hot), "hydro" (= water), and "philos" (= loving, fond of), with reference to the habitat preference of the new species. All materials examined were collected from submarine hot spring areas of Kagoshima Bay.

Distribution.-Known only from the eastern end of Kagoshima Bay at depths of $90-115 \mathrm{~m}$. The shrimps were always collected from in or around colonies of Lamellibrachia satsuma Miura, Tsukahara \& Hashimoto, 1997 and an- 
other unidentified polychaete tube worm, growing at the hydrothermal vent fields.

\section{Discussion}

Morphological comparison with congeners

The present new species differs from more than 130 shallow-water species of Periclimenes in having the combination of the following characters. The carapace is provided with an antennal spine and an epigastric spine or tubercle, but without a supraorbital spine. The rostrum is slender, without dorsal crest. The carpus, merus and ischium of the second pereopod are unarmed. The ambulatory pereopods have biunguiculate dactyli. Two pairs of spines are present on the dorsolateral surface of the telson. These characters, on the other hand, are shared by the following seven deep-water congeners: $P$. involens Bruce, 1996, $P$. laccadivensis (Alcock \& Anderson, 1894), P. latipollex Kemp, 1922, P. ordinarius Bruce, 1991b, $P$. richeri Bruce, 1990, $P$. tenuirostris Bruce, 1991a, and P. vaubani Bruce, 1990.

The new species, however, differs from these deep-water species in having the submarginal antennal spine, the base of which is located slightly inside the anterolateral margin of the carapace and no part of the base of the spine is on the margin. The antennal spine is marginal in all other species. The second pereopods in the new species are similar in shape and usually unequal in length, and the carpus is 0.8 or 1.0 times of the palm length. Including $P$. laccadivensis and $P$. vaubani, which have the unequal second pair of pereopods, all other species have a short carpus of the second pereopod, less than half of the palm length, although in $P$. ordinarius and $P$. richeri, only one side is known.

The new species, moreover, differs from $P$. tenuirostris in having smooth abdominal somites, not strongly produced into a carinate lobe on the third somite.
Periclimenes ordinarius differs from the present new species in the large hepatic spine on the carapace and the ogival shaped cornea. Periclimenes richeri and $P$. ordinarius bear a tubercle instead of an epigastric spine. In the new species the hepatic spine and the cornea are of normal shape and size. The epigastric spine usually is present far from the most posterior tooth of the rostral series and the dorsal margin between them is concave in lateral view. A tubercle is also discernable just behind the epigastric spine in largesized specimens. These features of the epigastric region are characteristic of the new species.

In $P$. latipollex, $P$. ordinarius, and $P$. richeri, the rostrum is relatively long, reaching or overreaching the distal end of the antennular peduncle, but falls short of it in the new species. In $P$. involens the rostrum does not reach the end of the antennular peduncle, but it is actually long, as long as the carapace length, while in the new species it is only $0.5-0.7$ times as long.

In $P$. latipollex, $P$. ordinarius, $P$. richeri and $P$. vaubani, the accessory tooth on the ventral margin of the corpus of the ambulatory dactyli is much smaller than the unguis, while in the remaining four species including the new species it is a considerable size.

\section{Consideration to the distribution}

Periclimenes thermohydrophilus is the only member of the family Palaemonidae represented at hydrothermal vent fields (Desbruyéres \& Segonzac, 1997; Tunnicliffe $e t a l, 1998)$. The shrimp was always found from the samples sucked from colonies of hard tubes of the vestimentiferan worm, Lamellibrachia satsuma, as well as soft tubes of unidentified polychaete tube worms. These worms are the typical associates of the so-called "tagiri," hydrothermal vent fields, around the eastern end of Kagoshima Bay at depths of about $100 \mathrm{~m}$ (Miura et al., 1997). 
Judging from the collecting data, the shrimp is restricted to these vent fields only and has not been obtained from any other parts of that bay, where more than 300 hauls were taken by the junior author from 1993. This is probably the first pontoniine shrimp in association with the vestimentiferan or polychaete tube worms (Bruce, 1976; Chace \& Bruce, 1993; Monod \& Laubier, 1996), though the relationship between this shrimp and the host invertebrate has not clearly been established.

The genus Periclimenes is mostly composed of shallow-water inhabitants (Chace \& Bruce, 1993), whereas most of the specimens we examined were collected at about $100 \mathrm{~m}$ deep, which is considered to be deep for most species of this genus. This is not an extreme depth, because about 35 species have been reported from depth of more than $100 \mathrm{~m}$ (Bruce, 1991b, 1996).

The following five species have been collected from deep waters around Japan; P. alcocki Kemp, 1922 from Tosa Bay, and Kumanonada, in 311-400m (Kubo, 1940; Hayashi, 1986), P. curvirostris Kubo, 1940 from off Owase, Mie Prefecture, in $311 \mathrm{~m}$ (Kubo, 1940), P. granuloides Hayashi, 1986 from Tosa Bay in $130 \mathrm{~m}$ (Hayashi, 1986), P. hertwigi Balss, 1913 from Suruga Bay to East China Sea off Kushikino, Kagoshima Prefecture, in 45311 m (Balss, 1913, 1914; Kubo, 1940; Fujino \& Miyake, 1970; Okuno \& Minemizu, 1998) and P. macrophtalmus Fujino \& Miyake, 1970 from East China Sea, off Goto Islands in $145 \mathrm{~m}$ (Fujino \& Miyake, 1970). P. curvirostris, $P$. granuloides and P. macrophtalmus have only been known from the type locality, while $P$. alcocki and $P$. hertwigi have also been recorded from other localities of the Indo-West Pacific region at depths down to more than $600 \mathrm{~m}$ (Chace \& Bruce, 1993).

The hosts of these deep-water shrimps are not known, except for $P$. hertwigi. It was originally collected from an echinoid host, Phormosoma sp. (Balss, 1913). The subsequent collections, moreover, were from the echinoids, Areosoma thetidis $(\mathrm{H}$. L. Clark) or A. owstoni Mortensen (Bruce, 1975; Okuno \& Minemizu, 1998). Bruce (1990) also suggested echinoid hosts for $P$. curvirostris.

The body color of the new species is entirely crimson red and clearly differs from cryptic, disruptive or transparent patterns often seen in the shallow-water congeners (Bruce, 1976). The body does not show any unusual parts and the eggs are small and numerous in number, which means that the shrimp probably has long-lived planktotrophic larvae and is highly mobile adults. This shrimp, therefore, should be found from other shallow water hydrothermal vent fields.

\section{Acknowledgments}

We would like to thank Dr. Tomoyuki Miura of Miyazaki University for collecting and donating this interesting material for us and Dr. Mary K. Wicksten of Texas A\&M University and Dr. Junji Okuno of Coastal Branch of Natural History Museum and Institute, Chiba for critical reading of the manuscript. The junior author thanks Dr. Jun Hashimoto of Japan Marine Science and Technology Center, technical operators and crew of "Shinkai 2000," "Dolphin 3K" and the mother ship "Natsushima" for capable support at sea.

\section{Literature Cited}

Alcock, A., \& Anderson, A. R., 1894. An account of a recent collection of deep-sea Crustacea from the Bay of Bengal and Laccadive Sea. Natural History Notes from H. M. Indian Marine Survey Steamer "Investigator", Commander C. F. Oldham, R. N., commanding. Ser. II, No. 14, Journal of Asiatic Society of Bengal, 63: 141-185, pl. 9.

Balss, H., 1913. Diagnosen neuer Ostasiatischer Macruren. Zoologischer Anzeiger, 42: 234-239.

_, 1914. Ostasiatsche Decapoden II. Die 
Natantia und Reptantia. Abhandlungen der Bayerischen Akademie der Wissenschaften, München, supplement, 2: 1-101, $1 \mathrm{pl}$.

Bruce, A. J., 1975. Periclimenes colemani sp. nov., a new shrimp associate of a rare sea urchin from Heron Island, Queensland (Decapoda Natantia, Pontoniinae). Records of the Australian Museum, 29: 486-501.

- 1976. Shrimps and prawns of coral reefs, with special reference to commensalism. In: O. Jones, \& R. Endean, (eds.), Biology and Geology of Coral Reefs, 3: 37-94, Academic Press, New York.

- 1990. Crustacea Decapoda: Deep-sea palaemonoid shrimps from New Caledonian waters. In: A. Crosnier, (ed.), Résultats des Campagnes MUSORSTOM, vol. 6 (5). Mémoires du Muséum national d'Histoire naturelle, 145: 149-215.

, 1991a. Shallow-water palaemonid shrimps from New Caledonia (Crustacea: Decapoda). In: B. Richer de Forges, (ed.), Le benthos des fonds meubles des lagons de Nouvelle-Calédonie, 1. Études et Théses, Paris, ORSTOM: 221-279.

$\longrightarrow$, 1991b. Crustacea Decapoda: Further deep-sea palaemonoid shrimps from New Caledonian waters. In: A. Crosnier, (ed.), Résultats des Campagnes MUSORSTOM, vol. 9 (8). Mémoires du Muséum national d'Histoire naturelle, 152: 299-411.

, 1994. A synopsis of the Indo-West Pacific genera of the Pontoniinae (Crustacea: Decapoda: Palaemonidae). Theses Zoologicae, 25: 1-172.

- 1996. Crustacea Decapoda: Palaemonoid shrimps from the Indo-West Pacific region mainly from New Caledonian. In: A. Crosnier, (ed.), Résultats des Campagnes MUSORSTOM, vol. 15 (7). Mémoires du Muséum national d'Histoire naturelle, 168: 197-267.

Chace, F. A., Jr., \& Bruce, A. J., 1993. The caridean shrimps (Crustacea: Decapoda) of the Albatross Philippine Expedition 19071910, part 6: Superfamily Palaemonoidea. Smithsonian Contributions to Zoology, 543: 1-152.

Christoffersen, M. L., 1986. Phylogenetic relationships between Oplophoridae, Atyidae, Pasiphaeidae, Alvinocarididae Fam. N., Bresiliidae, Psalidopodidae and Disciadidae (Crustacea Caridea, Atyoidea). Boletim de Zoologia, Universidade de Sao Paulo, 10: 273-281.

Costa, O. G., 1844. Su due nuovi generi di
Crostacei decapodi Macrouri Nota. Annali delle Accademia degli Aspiranti Naturelisti, Napoli, 2: 285-290.

Desbruyéres, D., \& Segonzac, M., 1997. Handbook of Deep-Sea Hydrothermal Vent Fauna. 279 pp., IFREMER, Brest, France.

Fujino, T., \& Miyake, S., 1970. Caridean and stenopodidean shrimps from the East China and the Yellow Sea (Crustacea, Decapoda, Natantia). Journal of the Faculty of Agriculture, Kyushu Uniersity, 16: 237-312.

Gebruk, A. V., Galkin, S. V., Vereshchaka, A. L., Moskalev, L. I., \& Southward, A. J., 1997. Ecology and biogeography of the hydrothermal vent fauna of the Mid-Atlantic Ridge. Advances in Marine Biology, 32: 93144.

Hashimoto, J., Miura, T., Fujikura, K., \& Ossaka, J., 1993. Discovery of vestimentiferan tube-worms in euphotic zone. Zoological Science, 10: 1063-1067.

Hayashi, K., 1986. Prawns and shrimps. In: K. Baba, K. Hayashi, \& M. Toriyama, (eds.) Decapod Crustaceans from continental shelf and slope around Japan. Fiscal 1985 Project Entrusted by the Fisheries Agency of Japan, 38-149, 232-279, Fisheries Resource Conservation Association, Tokyo.

Kemp, S., 1922. Notes on Crustacea Decapoda in the Indian Museum. XV. Pontoniinae. Record of the Indian Museum, 24: 113-288, pls. $3-9$.

Kubo, I., 1940. Studies on Japanese palaemonoid shrimps. II. Pontoniinae. Journal of the Imperial Fisheries Institute, Tokyo, 34: 31-75.

Miura, T., Tsukahara, J., \& Hashimoto, J., 1997. Lamellibrachia satsuma, a new species of vestimentiferan worms (Annelida: Pogonophora) from a shallow hydrothermal vent in Kagoshima Bay, Japan. Proceedings of the Biological Society of Washington, 110: 447-456.

Monod, T., \& Laubier, L., 1996. Les Crustacés dans la biosphère. In: J. Forest (ed.), Généralités (suite) et Systématique. Traité de Zoologie Anatomie, Systématique, Biologie. Crustacés. 7: 91-166.

Okuno, J., \& Minemizu, R., 1998. A record of a pontoniine shrimp, Periclimenes hertwigi Balss, 1913 (Crustacea, Decapoda, Palaemonidae) from shallow area, off Izu Peninsula, Japan. Chiba Seibutsushi, 48: 74-77.

Tunnicliffe, V., McArthur, A. G., \& McHugh, D., 1998. A biogeographical perspective of the deep-sea hydrothermal vent fauna. Ad- 
vances in Marine Biology, 34: 355-442.

Vereshchaka, A. L., 1997. A new family for a deep-sea caridean shrimp from North Atlantic hydrothermal vents. Journal of the Marine Biological Association of the United Kingdom, 77: 425-538.

Addresses: (KH) Department of Applied
Aquabiology, National Fisheries University, 27-1 Nagata-honmachi, Shimonoseki 759-6595, Japan; (JO) Faculty of Fisheries, Kagoshima University, 4-50-20 Shimoarata, Kagoshima 890-0056, Japan

E-mails: (KH) hayashik@fish-u.ac.jp; (JO) ohtomi@fish.kagoshima-u.ac.jp 